\title{
I GEDE GERUH \\ PRNGUKUH DAN PENGOKOH DRAMATARI GAMBUH DESA PEDUNGAN, KOTA DENPASAR
}

\author{
Oleh \\ Ni Nyoman Wahyu Adi Gotama \\ Dosen Fakultas Pendidikan Agama Dan Seni UNHI \\ M4nkwin@Gmail.Com
}

\begin{abstract}
ABSTRAK
Penelitian ini mengangkat topik tentang biografi I Gede Geruh serta kontribusinya terhadap kesenian gambuh di Desa Pedungan, Kecamatan Denpasar Selatan, Kota Denpasar. Keterlibatan I Gede Geruh dalam dramatari gambuh di Pedungan tidak hanya sebagai seorang penari, melainkan sebagai seorang guru atau pelatih dramatari gambuh dan juga sebagai pengurus dalam sekaa gambuh di Pedungan. Semua ini menunjukkan kebesaran peran dan totalnya keterlibatan I Gede Geruh dalam dramatari gambuh di Pedungan sebagai pengukuh dan pengokoh. Kata pengukuh digunakan untuk memposisikan I Gede Geruh sebagai seorang tokoh yang mempunyai peran penting agar nilai-nilai estetik Gambuh Pedungan tidak sampai berubah. Pengokoh digunakan untuk memposisikan Geruh sebagai seorang figur yang ibarat pilar yang mampu membuat kesenian Gambuh Pedungan tetap eksis ditengah-tengah perubahan nilai sosial dan budaya Bali. Kata pengokoh dimaknai sebagai seorang tokoh yang ibarat tiyang penyangga untuk menjaga "bangunan" sekaa gambuh ini jangan sampai roboh. Kehadiran seniman ini memiliki dampak yang cukup luas terhadap kehidupan kesenian, aktivitas upacara agama dan pembangunan sosial dan budaya di Desa Pedungan
\end{abstract}

Kata kunci : I Gede Geruh, pengukuh dan pengokoh, dramatari Gambuh Pedungan.

\section{ABSTRACT}

This study raised the subject of the biography I Gede Geruh and its contribution to the gambuh arts in the Pedungan village. In Bali, only a few villages having gambuh art. One village is famous for its gambuh art is Pedungan Village, District of South Denpasar, Denpasar . Historically, Gambuh Pedungan a palace of art which is closely related to Puri and Puri Satria acceleration. It gets protection of the authorities in both the castle. The amount of attention to the gambuh art king at that time led to Gambuh Pedungan grows and flourishes and bears gambuh dancers reliable. One of the gambuh dancers is very famous I Gede Geruh (deceased), a very large contribution to the preservation, development and sustainability Gambuh Pedungan . In his youth he was able to portray all the characters in the pegambuhan art.

This research uses qualitative and quantitative data that is widely used in research methods, social sciences and humanities. Source of data used mostly acquired through observation, interviews, literature data and documentation.

As analysis, research using biographical theory as the main theory and motivation theory, semiotic theory and aesthetic theory as the supporting theory. This study was also accompanied by the application of some concepts, approaches and frameworks references.Through the application of the theory of biography can be concluded that involvement 
in Gede Geruh in Pedungan dance drama not only as a dancer, but as a teacher or coach of dance drama gambuh and also as a board member in sekaa gambuh in Pedungan. This shows the greatness of all roles and their total involvement in dance drama of Gede Geruh in Pedungan as people who staunchly and leader. The word is used to position peple who staunchly I Gede Geruh as a character who has an important role that aesthetic values Gambuh Pedungan not to change. Leader used to position Geruh as a figure like a pillar that is able to make art Gambuh Pedungan still exist in the midst of changes in social values and culture. Said leader interpreted as a figures like pillar buffer to keep "building " is not to sekaa gambuh collapsed. The presences of these artists have a wide impact on the lives of art, ritual activity and social and cultural development in the Pedungan Village

Keywords: I Gede Geruh, people who staunchly and leader, dance drama Gambuh Pedungan

\section{PENDAhuluan}

Secara historis gambuh pedungan merupakan seni istana yang erat kaitannya dengan puri satria dan puri pemecutan. Gambuh mendapat perlindungan dan pengayoman dari penguasa kedua puri tersebut. Besarnya perhatian raja pada kesenia gambuh pada waktu itu menyebabkan gambuh pedungan tumbuh dan berkembang melahirkan penari-penari gambuh yang handal. Salah satu di antaranya yang sangat terkenal adalah I Gede Geruh.

I Gede Geruh adalah sebuah nama yang identik dengan masa kejayaan Gambuh Pedungan.

Semasa hidupnya I Gede Geruh ternyata merupakan figur kunci dalam sekaa gambuh di pedungan.I Gede Geruh adalah seorang penari popular ketika Gambuh Pedungan masih menjadi kesenian istana di Puri Satria dan Puri Pemecutan.
Sepeninggal I Gede Geruh keturunannya tidak lagi mewarisi bakatnya dalam menarikan Dramatari Gambuh, sehingga tidak ada penari yang benar-benar mampu menguasai kepiawaiaanya ketika menari dan membawakan seluruh karakter dalam Dramatari Gambuh.

I Gede Geruh sangat besar kontribusinya terhadap pelestarian, perkembangan, dan keberlanjutan Gambuh di Pedungan. Semua ini menunjukkan ketokohan seorang Gede Geruh yang selama ini belum banyak diketahui.

\section{II.PEMBAHASAN}

\section{Wujud Keterlibatan I Gede Geruh dalam}

\section{Dramatari Gambuh}

Masyarakat Pedungan mengakui bahwa keterlibatan I Gede Geruh dalam dramatari gambuh di Pedungan (Kecamatan Denpasar selatan) sangat menonjol. Wujud keterlibatan I Gede Geruh dapat dipilah menjadi tiga. Pertama, sebagai penari atau pelaku. Kedua, 
sebagai guru atau pelatih. Ketiga adalah sebagai anggota pengurus sekaa gambuh. Ketiga hal ini menunjukkan betapa sentralnya peran seorang I Gede Geruh dalam sekaa gambuh di Desa Pedungan

\section{Gede Geruh Sebagai Penari}

I Gede Geruh adalah seorang seniman tari yang identik dengan gambuh. Kepiawaian Geruh dalam membawakan dan menguasai berbagai macam karakter dalam penokohan dramatari gambuh ini tidaklah dikuasai dalam waktu yang singkat.Di Banjar Puseh Geruh pertama kali memulai proses belajar tari gambuh. Ketika terjadi proses belajarmengajar itulah kesenian gambuh mulai mengalami regenerasi hingga sekarang ini.

Ketika I Gede Geruh mulai beranjak dewasa ( ketika masa remaja), ia semakin tertarik untuk menggeluti dan mendalami gambuh dengan jalan belajar kepada beberapa orang seniman gambuh pendahulunya. Adapun seniman gambuh yang sempat menjadi guru atau pembina I Gede Geruh adalah I Nyonggol, I Teteng, dan Jero Mangku Sara, pemangku Pura Puseh, Desa Pedungan. Perlu diketahui bahwa selain sebagai penari gambuh, Jero Mangku Sara juga merupakan seorang dalang wayang kulit.

Mengawali pemahamannya tentang gambuh I Gede Geruh pertama kali mempelajari tari arya. Tari arya adalah salah satu tarian yang memiliki karakter keras dalam struktur Dramatari Gambuh. Tari arya merupakan salah satu tarian yang ditarikan oleh laki-laki yang memiliki karakter keras, tegas, dam pemberani. Tokoh ini berperan sebagai maha patih kerajaan yang terdiri dari empat orang dan bertugas sebagai pendamping raja keras dan pemimpin perang (Formaggia, 2000 : 243). Belajar gambuh adalah tergolong sebuah seni pertunjukan yang sakral yang digunakan sebagai persembahan dalam kaitannya dengan upacara keagamaan di Bali. Dapat dikatakan pula bahwa gambuh adalah sebuah tari bebali dari halam pura bagian tengah yang dipertunjukkan tanpa topeng. Dalam gambuh, aspek-aspek perilaku ideal kaum ningrat di era Majapahit dipertahankan, begitu pula gubahan musiknya, ide-ide koreografi dan nilai sastra adiluhung pada saat itu (Bandem, 2004 : 37).

\section{Gede Geruh Sebagai Guru atau Pelatih}

Sebagai pragina (penari) gambuh senior, yang menguasai hampir menguasai seluruh aspek seni pegambuhan, Gede Geruh juga mendapatkan kepercayaan menjadi seorang pelatih/ guru dalam dramatari gambuh di Pedungan. Seluruh pengetahuan gambuh yang diperoleh dari gurunya terdahulu, ia ajarkan kepada generasi muda yang ada di desanya. Komposisi, karakterisasi, gaya tari, termasuk teknis ngepah satua, paucapan, dan ngartos 
adalah materi yang diajarkan kepada muridmuridnya.

Pada saat setiap pementasan Gambuh Pedungan akan dimulai seluruh penari dikumpulkan terlebih dahulu untuk diberikan penjelasan tentang jalan cerita yang akan dipentaskan. Gede geruh selalu mengatur struktur pertunjukan sesuai dengan peranperan utama yang ada. Gede geruh seringkali mengacak, merubah dan mengganti bagianbagian pertunjukan setelah babak pertama yang dirasakan sudah memiliki struktur yang baku. Bagian kedua dan selanjutnya disesuaikan dengan jalannya lakon. Setelah struktur pertunjukan dipastikan, barulah ia masuk ke hal-hal detail seperti menjelaskan doalog yang harus diucapkan oleh setiap muridnya termasuk terjemahan oleh para punakawan. Beberapa lakon yang sering dibawakan dalam pertunjukan Dramatari Gambuh Pedungan adalah Galuh Nogog, Sangging Prabangkara, Puwun Alas, Puwun Pondok, dan Tuek Maesa Jayanti.

Sejak terbentuknya ASTI Denpasar di Bali pada tahun 1967, dramatari gambuh masuk menjadi mata kuliah/ materi perkuliahan. Dijadikannya gambuh sebagai materi perkuliahan di ASTI, tiada lain bertujuan untuk menyelamatkan kesenian klasik ini dari kepunahan. Mengingat bahwa kesenian ini tidak dimiliki oleh seluruh desa yang ada di Bali.

Peran I Gede Geruh dalam mengajarkan gambuh baik gerak tari maupun karakterisasinya membawanya menjadi salah satu tenaga pengajar dalam materi perkuliahan tersebut. I Gede Geruh sempat menjadi seorang dosen, walaupun tidak memiliki pendidikan formal. Hal ini disebabkan oleh kemampuan I Gede Geruh dalam menguasai berbagai jenis karakter dalam drama tari gambuh dirasakan memiliki karakterisasi yang kuat. Sehingga beliau dipercaya untuk mengajar gambuh yang kala itu menjadi salah satu mata kuliah di ASTI Denpasar.

I Gede Geruh Terjun Ke Seni Pegambuhan

Terkait dengan pemaparan di atas, terjunnya I Gede Geruh dalam seni pegambuhan dipengaruhi oleh dua faktor, yakni faktor internal dan faktor eksternal. Kedua faktor ini sangat mempengaruhi I Gede Geruh dalam berkesenian. Seorang seniman sebagai makhluk sosial tidak terlepas dari kondisi masyarakat dan lingkungannya serta situasi masanya. Maka hasil seni kecuali sebagai lambang pribadi seseorang sekaligus bidangnya merupakan lambang masyarakat, lingkungan serta zamannya.

\section{Faktor Internal}


Kiprah I Gede Geruh dalam seni gambuh tumbuh dan muncul begitu saja atas dorongan nalurinya sendiri, untuk ikut melestarikan kesenian gambuh yang ada di desanya. Terkait dengan hal tersebut Djelantik (2008 : 67) menyatakan bahwa ada tiga unsur yang mempengaruhi sebuah penampilan seorang penyaji seni antara lain bakat, keterampilan serta sarana atau media.

\section{Bakat}

Bakat adalah potensi kemampuan khas yang dimiliki oleh sorang, yang didapatkan berkat keturunannya. Secara biologis keturunannya itu ditentukan oleh kehadiran unsur-unsur genetik, yang disebut gen yang terletak pada kromosom dalam masing-masing sel dari tubuh mahkluk (Djelantik, 2008 : 67).

I Gede Geruh memang dilahirkan sebagai orang yang memiliki bakat, di samping dari warisan kakeknya. Bakat tari adalah anugrah atau pembawaan yang dapat dibangkitkan, dan dikembangkan tetapi tidak bisa dipaksakan atau tumbuh tanpa dilatih. Seorang yang tidak memiliki bakat istimewa tidak akan dapat berkreativitas dan menciptakan karya yang berarti, meskipun dia menunjang perkembangan kreativitas. Bakat juga merupakan pembawaan sejak lahir yang memungkinkan bagi orang bersangkutan untuk dapat lebih mudah dan lebih cepat berhasil menguasai suatu keterampilan.

\section{Keterampilan}

Keterampilan adalah kemahiran dalam pelaksanaan sesuatu yang dicapai dengan latihan. Taraf kemahiran tergantung dari cara melatih dan ketekunannya melatih diri. Cara melatih tidak kurang pentingnya daripada ketekunan. Hal ini diketahui oleh para seniman, guru tari dan para guru seni pentas lainnya (Djelantik, 2008 : 68).

Keterampilan yang dimiliki oleh I Gede Geruh pada masa hidupnya merupakan hasil latihan yang dilakukan secara tekun. Berbekal dari ilmu-ilmu seni yang diajarkan oleh kakeknya, I Gede Geruh tetap melestarikan apa yang diajarkan tersebut tanpa menghilangkan petuah dari kakeknya.

\section{Sarana atau Media}

Selain bakat dan keterampilan yang dimiliki oleh I Gede geruh, sarana atau media juga berperan penting dalam aktivitas berkeseniannya. Tempat latihan berupa bale banjar merupakan salah satu sarana yang digunakan sebagai tempat latihan dan mengajar oleh I Gede Geruh. Selain tempat latihan, ditinjau dari sruktur organisasi, keadaan penari, penabuh termasuk saranasarana pendukungnya seperti alat gamelan dan busana tari merupakan salah satu sarana yang dimiliki oleh sekaa gambuh di Pedungan. Sarana ini yang mendukung setiap penampilan I gede Geruh saat pentas. 


\section{Faktor Eksternal}

Faktor eksternal merupakan faktor yang ikut mempengaruhi I Gede Geruh terjun dalam seni pegambuhan. Faktor ekternal meliputi keadaan geografis lingkungan serta kondisi masyarakat. Dengan memperhatikan faktor internal tersebut dapat diketahui mengapa I Gede Geruh menekuni seni pegambuhan.

\section{Kondisi Masyarakat}

Kondisi masyarakat sangat berpengaruh terhadap aktivitas berkesenian I Gede Geruh. Demikian juga bahwa kiprah seniman I Gede Geruh yang telah melestarikan kesenian gambuh. Adanya dorongan dari seorang gurunya yang secara fisik dan artistik sangat menguasai hakekat seni pegambuhan, telah memicu semangat para generasi untuk terus melestarikan tari klasik ini. Sebagai sumber dan bentuk tari Bali, dengan keklasikannya yang nampak pada struktur dan sistem pementasannya yang menggunakan patokan (uger-uger) gerak tari, pendramaan dan tabuh iringannya. Memahami bahwa dramatari gambuh yang ada di Desa Pedungan adalah warisan budaya yang bernilai sakral dan sosial, Gede Geruh senantiasa menggali dan menekuni seni pegambuhan ini.

\section{Lingkungan}

Lingkungan juga berpengaruh sangat kuat terhadap aktivitas berkesenian Gede
Geruh. Di Desa Pedungan, tempat ia tinggal merupakan lingkungan yang merupakan tempat tumbuh dan berkembangnya kesenian gambuh. Salah satu faktor terpenting yang mendorong para pragina tersebut untuk terjun ke dalam dunia seni pentas adalah lingkungan: tradisi berkesenian di lingkungan keluarga dan di kalangan masyarakat setempat. Dalam kaitannya dengan lingkungan, ada tiga alas an bagi para pragina untuk terjun ke dalam bidang kesenian yaitu: ditunjuk atau diminta, bahkan 'dipaksa' oleh warga masyarakat, dorongan atau panggilan keluarga, dan kemauan sendiri (Dibia, 2004 : 114). Dari lingkungan yang memiliki darah seni, secara tidak langsung Gede Geruh juga ikut mempelajari kesenian gambuh ini dan mampu mewarisinya pada generasi penerusnya. Namun sekarang ini di keluarga Gede Geruh tidak ada lagi yang mewarisi kesenian ini. Namun kesenian ini masih dilestarikan oleh masyarakat sebagai kesenian sakral dan sosial.

\section{Makna Kehadiran I Gede Geruh Dalam} Dramatari Gambuh Pedungan

\section{Makna Sosial}

Makna sosial yang yang terkandung dalam kehariran I Gede Geruh dapat dilihat dari adanya hubungan interaksi maupun komunikasi yang terjalin secara langsung maupun tidak langsung antara anggota sekaa 
gambuh. Interaksi sosial antar anggota sekaa yang menampilkan pertunjukan dramatari gambuh di pedungan ini ditunjukkan oleh hubungan antara I Gede Geruh dengan anggota sekaa yang lain mengandung makna sosial, yakni sebagai media interaksi antara anggota sekaa dengan Gede Geruh. Dengan adanya pementasan pada saat piodalan atau acara lainnya para anggota sekaa bisa berkumpul dan berinteraksi satu sama lain, sehingga mampu menumbuhkan rasa solidaritas diantara mereka. Interaksi sosial antara anggota sekaa dengan I Gede Geruh, yakni terjadi pada saat pertemuan antara kedua belah pihak untuk membahas mengenai proses latihan dan pementasan. Seni menyandang makna sosial yang bersifat manusiawi karena hakekat seni adalah untuk dikomunikasikan, yang berarti untuk dinikmati, ditonton, didengar, atau diresapi secara kolektif. Kehadiran seni mencakup tiga faktor yang saling berhubungan yakni pencipta, hasil karya seni, dan pengamat atau penonton (Hadi, 2000 : 332).

\section{Makna Estetik}

Sebagai seorang seniman kehadiran Gede Geruh tentu mengandung sebuah makna estetik (keindahan), karena di dalamnya mengandung unsur-unsur estetika yang terdiri dari tiga aspek yakni : wujud atau rupa (appearance), bobot atau isi (substance), dan penampilan atau penyajian (presentation) (Djelantik, 2008 : 17). Dilihat dari fisiknya Gede Geruh yang memiliki postur tubuh yang tinggi dan besar, sangat cocok untuk memerankan tokoh prabangsa, tokoh yang selalu diperankan oleh Gede Geruh.

Dari uraian di atas menunjukkan bahwa I Gede Geruh menekuni tari keras antara lain prabu, arya dan prabangsa dengan bawaan atau abah tarian yang khas, gede geruh mampu menguasai masing-masing karakter. Pakem yang dikuasai secara umum dan khusus agak sulit untuk ditangkap apabila tidak dipelajari dengan serius. Ada gerakangerakan yang memiliki cirri khas dalam gerakan prabu keras yang disebut ngunda sari dan nyigug, yang sulit ditangkap.

\section{Makna Spiritual}

Selain makna sosial dan makna estetis juga terdapat makna spiritual yang mendukung I Gede Geruh sehingga mampu menjadi seorang seniman yang memiliki taksu dalam membawakan setiap karakter pada saat pembelajaran maupun pementasan dramatari gambuh di pedungan. Masyarakat Hindu di Bali umumya percaya bahwa taksu adalah kekuatan suci yang dapat membangkitkan dan meningkatkan kemampuan seorng seniman dalam aktivitas berkesenian baik itu menciptakan sebuah karya baru ataupun membawakan sebuah kesenian. Taksu pada 
dasarnya adalah kekuatan spiritual atau energi khusus yang dapat mengubah sesuatu yang biasa menjadi luar biasa, mengubah manusia menjadi makhluk super, dan membuat benda sehari-hari menjadi benda khusus. Ketika taksu bermanifestasi baik dalam benda, kegiatan, dan budaya atau pada seseorang serta suatu tempat, maka seseorang akan menangkap atau merasakan sesuatu yang sangat istimewa dan mempesona di dalamnya (Dibia, 2012 : 24).

\section{PENUTUP}

\section{Simpulan}

Berdasarkan uraian-uraian di atas, dapat disimpulkan bahwa kemunculan I Gede Geruh sebagai seorang tokoh panutan dalam dramatari gambuh di Pedungan ini, dilatar belakangi oleh adanya dramatari gambuh di Pedungan sebagai kesenian istana yang diayomi pemerintah. Gambuh telah mengalami pasang surut dalam seni pertunjukan di Bali. Berkat kehadiran tokoh seniman asal Banjar Puseh Desa Pedungan ini gambuh dapat direkontruksi kembali. Sebagai kesenian klasik yang merupakan warisan leluhur, maka I Gede Geruh menganggap sebuah keharusan untuk melesatarikan kesenian tersebut.

Karena loyalitasnya terhadap kesenian gambuh ini I Gede Geruh memperoleh beberapa penghargaan dari pemerintah. Penghargaan yang dimilikinya antara lain "Kerti Budaya" dari Pemda Badung tahun 1973, tanda penghargaan sebagai dosen luar biasa ASTI Denpasar tahun 1979, Piagam Dharma Kusuma Madya dari Pemda Bali tahun 1981, cincin emas "Ciwa Nata Raja" dari STSI Denpasar tahun 1994 dan penghargaan terakhir yang diperolehnya adalah penghargaan dari K. Nadha Nugraha tahun 2009 dan K. Nadha Nugraha tahun 2010.

\section{DAFTAR SUMBER}

Bandem, I Made. 1975. Panitithalaning Pegambuhan. Denpasar : Proyek Percetakan/Penerbitan Naskah-naskah Seni Budaya.

Bandem, I Made, dan Fredrik Eugene deBoer. 2004. Kaja dan Kelod : Tarian Bali dalam Tradisi. Terjemahan I Made Marlowe Makaradhwaja Bandem. Yogyakarta: Institut Seni Indonesia Yogyakarta.

Bungin, Burhan. [2003] 2008. Analisis Data Penelitian Kualitatif : Pemahaman Filosofis dan Metodologis ke Arah Penguasaan Model Aplikasi. Jakarta : PT. Raja Grafindo Persada. 
Dibia, I Wayan. 1999. Selayang Pandang Seni Pertunjukan Bali. Bandung: Masyarakat Seni Pertunjukan Indonesia Arti Line. . 2004. Pragina : Penari, Aktor dan Pelaku Seni PertunjukanBali. Malang: Sava Media . 2012. Taksu Dalam Seni

Dan Kehidupan Bali. Denpasar: Bali Mangsi

. 2012. Mongkah Tanah

Mungkah Lawang : Biografi Seniman I

Wayan Geria. Yogyakarta : Kanisius.

Formagia, Maria Cristina. 2000. Gambuh

Drama Tari Bali Jilid I. Jakarta : Jayakarta Agung Offset. 2000. Gambuh Drama

Tari Bali Jilid II. Jakarta : Jayakarta Agung Offset.

Kaelan. 2009. Filsafat Semiotika dan Hermeneutika, Yogyakarta : Paradigma.

Kayam, Umar. 1981. Seni, Tradisi, Masyarakat. Jakarta: Penerbit Sinar Harapan

Koentjaraningrat. 2010. Sejarah Teori Antropologi I. Jakarta: Universitas Indonesia.

2010. Sejarah Teori

Antropologi II. Jakarta : Universitas Indonesia.
Marianto, M. Dwi. 2002. Seni Kritik Seni. Yogyakarta : Lembaga Penelitian ISI Yogyakarta.

Nadya Abrar, Ana. 2010. Bagaimana Menulis Biografi : Perspektif Jurnalisme. Sleman, Yogyakarta: Emerson.

Pemda Kodya Denpasar. 1999. Sosok Seniman dan Sekaa Kesenian Kota Denpasar. Denpasar : Tim Humas Kodya Denpasar. Piliang, Yasraf Amir. 2003. Hipersemiotika : Tafsir Cultural Studies Atas Matinya Makna. Yogyakarta : Jalasutra.

Soedarsono, RM dan Tati Narawati. 2011. Dramatari di Indonesia, Komunitas dan Perubahan. Yogyakarta : Gadjah Mada University Press.

Uno, B Hamzah. 2012. Teori Motivasi dan Pengukurannya. Jakarta: PT Bumi Aksara 